\title{
MORE THOUGHTS ON SCHOLARLY MISCONDUCT, AND WHAT WE CAN LEARN FROM IT

\author{
A Critical Response to Peter Jan Margry's \\ Article about the Bax Affair
}

\author{
Oscar Salemink, Professor of Anthropology, University of Copenhagen (formerly Professor of \\ Anthropology, Vrije Universiteit, Amsterdam) \\ Jojada Verrips, Emeritus Professor of Anthropology, University of Amsterdam
}

\section{Introduction}

On 9 September 2013 a commission consisting of Prof. Michiel Baud (University of Amsterdam), Prof. Susan Legêne (Vrije Universiteit Amsterdam) and Prof. Peter Pels (Leiden University) presented the report "Circumventing Reality: Report on the Anthropological Work of Professor Emeritus M.M.G. Bax", which they had drafted at the request of the Vrije Universiteit Amsterdam (from now on: VU) in the Netherlands. The anthropologist Mart Bax, who as professor of anthropology at the VU had practically retired in 2001 and formally in $2002,{ }^{1}$ was shown to be a fraud, who made up numerous (non-existing) publications, and who had published about events (in Medjugorje, Bosnia) that never happened, and about places (in the province of Noord-Brabant, the Netherlands) that did not exist. This non-existing "empirical" material formed the basis for Bax's theory of "religious regimes" and his academic career. Given Bax's refusal to share information and sources about these events and places with the commission, they could not, however, positively prove that these events and places were invented. Yet, given the absence of historical evidence that a violent conflict had occurred between different Catholic groups in
Medjugorje, Bax went down in the report and in history as a scientific confabulator and fraud.

In his scholarly career Bax had published seven articles in Ethnologia Europaea. Seven years after Bax was exposed as a fraud, his articles in Ethnologia Europaea were withdrawn, as announced by the journal editors Marie Sandberg and Monique Scheer in their editorial "Fabricating Data, Undermining Trust, or: Why We Omitted Work from Our Digital Archive" (Sandberg \& Scheer 2019). This was accompanied by an article by Peter Jan Margry (2019) titled "On Scholarly Misconduct and Fraud, and What We Can Learn from It". The article is a mix of his personal reminiscences of the Bax "affair" in the Netherlands since the early 2000s, and a "lessons learned" part towards the end. This article is in our view highly problematic. Since Margry mentions both of us in the article as somehow implicated in what we feel he portrays as "Dutch anthropology's cover-up" of Bax's fraud in the 2000s, and since he refers to personal e-mail correspondence with both of us, we feel compelled to respond. We agree that the Bax case is a horrendous affront to scholarly ethics, and it is important that this case is held up as a model not to follow. Margry states in his article that humanities 
and social science researchers share an important responsibility, namely "to deal ... precisely, meticulously, and ethically ... with sources and data and their interpretation" (2019: 141). We could not agree more. Thus, it is important to also scrutinize his use of his sources, which leaves much to be desired, as we shall show.

The analysis of the Bax affair at the occasion of the withdrawal of his Ethnologia Europaea articles deserves a better burial speech. After all, when writing about misconduct, the requirement of ethical sincerity, and of methodological, empirical and analytical precision is no less stringent. In this contribution we aim to not only clear our names, but to set the record straight and to offer some food for thought about the replicability and falsifiability of qualitative research (i.e. not just anthropological or ethnological), that is simultaneously guided by past and present professional ethical codes and privacy standards. And to be crystal clear, our critique of the analysis of Margry is in no way meant to somehow exonerate Bax or excuse his fraud. In the next sections we show a number of empirical imprecisions in Margry's article, followed by a section on the difficulty in falsifying qualitative research. Subsequently, we argue that Margry's (mis)interpretations serve to construct a narrative which pits ethnology against anthropology and which is unhelpful given the similarities between these disciplines and the impact of the current research ethics regime under the EU's General Data Protection Regulation (GDPR). We finally argue that rather than thinking in terms of "data", it would be more helpful and respectful to fully restore the human subjectivity of research subjects.

\section{Empirical Imprecisions in Margry's Narrative}

In the early 1990s a number of serious doubts cropped up in various scholarly circles over the veracity of Mart Bax's empirical descriptions in a number of his publications. Before his retirement in 2002, Bax was an anthropologist at the VU, and working primarily with the theories of Norbert Elias. He was a well-known figure within the group of so-called figuration sociologists in Amsterdam, but much less known among anthropologists in Amsterdam and elsewhere in the Netherlands. We would say that within Dutch anthropology he was a rather peripheral figure, and he was known to resent that lack of recognition. His main claim to fame was his theory of religious regimes, which he had developed on the basis of (purported) research in Ireland, Brabant and Bosnia.

Dutch historians questioned Bax's historical narrative of an intra-church conflict between a bishop and a monastic order in Brabant, and even doubted the existence of the monastery in question, because Bax worked with pseudonyms - calling the monastery "Neerdonk" - and did not provide sources for his stories. And in 2008, German, Austrian and Croatian scholars and journalists began to question Bax's narrative of a violent conflict between the Catholic Church hierarchy and the Franciscan order in the Marian pilgrimage site of Medjugorje. All of this Margry recounts, but the way that he presents the various responses to these doubts and allegations among Dutch anthropologists diverges from the historical record as based on written and e-mail correspondence that involves both authors (Verrips and Salemink) variously and in different capacities.

In his article Margry describes (2019: 134) what he did in the period 2003-2006 to make public that Bax's inaugural lecture "The Humiliation of a Saint", held in October 1989 at the VU in Amsterdam, contained all kinds of fictive elements. In so doing, he is not very precise. He speaks about the fact that he - almost ten years after his first meeting with Bax - wrote him, and how he "then [italics added] approached colleague-historians from Noord-Brabant, just to check if they might have data I had overlooked" (ibid.). But endnote 5 is crystal clear about the fact that Margry did not approach his colleagues from Brabant, Arnoud-Jan Bijsterveld and Jan Peijnenburg, after his letter to Bax in November 2003, but already in the middle of August of that year. According to Margry both scholars informed him that they "were puzzled too" about Bax's inaugural lecture on the monastery in "Neerdonk". A third colleague, Charles Caspers, presented a more subtle judgment, though he also had his objections. ${ }^{2}$ 
It is remarkable that the four historians from Brabant (Margry included) at the time refrained from writing a probing scholarly critique of Bax's narrative of events in the monastery in "Neerdonk".

In the months that followed, Margry, according to his own account, remained concerned about Bax's fabrications. He decided in 2005 to approach a few of Bax's anthropological colleagues who had commented on his inaugural lecture with the question of what could be done in order to reveal Bax's fiddling with historical and ethnographic facts. "None of them was able to give me any solution either," he laments (2019: 135). It is remarkable that Margry keeps silent about the fact that he had already been in contact with Verrips since the spring of 2003 about Bax's fantasies with regard to his monastery in Brabant and what to do about them. Margry sent Verrips, among other things, a copy of a letter he had written to the three historians in Brabant (see note 2), and they engaged in an e-mail correspondence at the end of 2003 and the beginning of 2004. All this did not lead to what Margry wanted, that is concrete action by Verrips and further colleagues the latter had approached, like Bax's Ph.D. thesis supervisor Jeremy Boissevain. Instead Verrips informed Margry in the beginning of 2004 about Boissevain's advice to approach Bax once again with the growing rumours about the fake character of his work on "Neerdonk", and that it therefore was high time to reveal the real name of the monastery he had studied and to be open about his sources. ${ }^{3}$ Margry did not follow that advice. When in March 2005 Verrips asked Margry if he had been in touch with Bax, he responded: No, he had not, and he did not know if he should let the case rest or not, because he himself was busy at the time with research in Bosnia. ${ }^{4}$

After a short e-mail exchange with Margry, Verrips decided to write a letter to Bax on 6 June 2005, in which he in plain terms asked Bax to tell where exactly in Brabant he had done his fieldwork and what kind of sources he had used, for Verrips wanted to get to the bottom of this affair. Bax answered his letter in a comprehensive but evasive way on 19 June 2005. It is from this letter to Verrips that Margry uses quotes in the endnotes 21, 22 and 23 without mentioning why Bax wrote this letter to Verrips. Just as Margry's omissions concerning his own contacts with Verrips, this omission appears to us to be a glaring lack of precision. After Margry's claim that the anthropologists whom he approached in 2005 did not know how to proceed in the Bax affair (2019: 135) - although at least one anthropologist, Verrips, had written a letter to Bax - he then recounts (2019: 135) that in 2008 he decided to contact "two of [Bax's] former anthropology colleagues" because of reports circulating that Bax had produced articles on Medjugorje on the basis of fabricated data. According to endnote 14, we (Verrips and Salemink) were these colleagues, but Margry does not point out that he had already been in contact with Verrips from 2003 to 2006.

The occasion in 2008 for contacting Verrips and Salemink - of which the latter was then head of the department of anthropology from which Bax had earlier retired - were a number of publications in German-language media concerning Bax's story (presented in articles in the journals Amsterdams Sociologisch Tijdschrift, Ethnologia Europaea and Ethnos) about a violent conflict between different Catholic factions in the Marian pilgrimage site of Medjugorje (Bosnia) in 1992, during which 140 people purportedly died and hundreds of others made refugees. Some newspapers had reported that, according to local Balkan experts and researchers, this "little war" had never happened. ${ }^{5}$ So, after years of rumours among Dutch historians about the impossibility to trace Bax's monastery in Brabant, similar claims had surfaced in the Balkans and in Germanlanguage media about Bax's fabrication of events in Bosnia-Hercegovina. When Margry contacted Verrips and Salemink again, the latter informed his superiors at the VU as well as a number of senior anthropologists from various Dutch, German and Austrian universities. This led to a multilateral e-mail correspondence in the fall of 2008 between Salemink, Verrips and other anthropologists about the best course of action, and where various options were discussed. ${ }^{6}$ Some colleagues advocated to keep silent, hoping that the storm would blow over in time. Others felt that the case should be investigated 
as a violation of research ethics that, however, would require an enormous investment of expertise and time that we all lacked, given our otherwise busy schedules. Instead, a third option was adopted, namely to write a scholarly rebuttal of Bax's assertions, and a challenge to him to disclose the sites of his research and his sources.

The last option appeared to be the ideal solution, and a small group of colleagues took it upon themselves to write such an article. This small group consisted of Margry, Verrips and Salemink who combined different types of expertise: Margry as a historian and ethnologist of the Netherlands specializing in Brabant at the time; Verrips as a historicizing anthropologist focusing on the Netherlands and Europe; and Salemink as an anthropologist and historian geographically focusing on Vietnam, and substantively on uses of ethnography and on anthropological research ethics. As an editor at the time of the journal Focaal - Journal of Global and Historical Anthropology, Salemink ensured that there was interest in publication of such an article. This however required expertise about Bax's geographic and substantive foci and investment of an amount of time that was difficult to combine with other teaching, research and administrative responsibilities. First, Verrips had to withdraw from the project because of illness, whereupon Margry withdrew because he felt uncomfortable to write as an ethnologist about the failures of an anthropologist - a sentiment that he also expresses in his article here (2019: 135). As basically an anthropologist of Southeast Asia at the time, Salemink felt incompetent to comment on Bax's research in Brabant and Bosnia on his own and at the same time, he experienced health issues which kept him away from his desk for a year.

In short, the plan to write an article questioning the veracity of Bax's oeuvre about Brabant and Bosnia fell through, but not for the reasons given by Margry, namely reluctance on the part of Verrips and Salemink in September-October 2008: "I therefore asked two of his former anthropology colleagues if they would join me in writing an article on the findings and on how to deal with verifiability and sources in scholarly work. Both replied that they indeed had their doubts about Bax's work, but that they could not bring themselves to believe that he had committed fraud. Making the case public was also likely to cause collateral damage by hurting the university, its department of anthropology, and the field at large. They kept faith in the academic oath Bax had taken after his Ph.D. defence on 16 November 1973" (Margry 2019: 135). This short passage contains, in our view, absolute nonsense on no less than three fronts. First, neither Verrips nor Salemink harboured much doubt that Bax had committed fraud - why else were they planning to write an article to offer a rebuttal of Bax's findings, even if it did not materialize? Second, the idea that Verrips and Salemink would have kept faith in Bax's purported academic oath is even greater nonsense: it never came up, not least because in 1973, Ph.D. candidates at the University of Amsterdam did not swear an academic oath. Third, the sentence that "Making the case public was also likely to cause collateral damage by hurting the university, its department of anthropology, and the field at large" is a paraphrase anachronistically taken from an email of 25 October 2012 from Salemink to Verrips and Margry, after Bax's fraud had been publicized by the journalist Van Kolfschooten, and four years after the discussion over writing an article to engage with the suspicions around Bax's misconduct. In other words, Margry uses a sentence from an email from 2012 to explain why in 2008 Dutch anthropologists would have been reluctant to make Bax's confabulations public. Salemink's literal point in that e-mail was that the publicity (which in his view had been inevitable) over Bax's scientific fraud was "bad for anthropology, bad for anthropology at the VU". That said, the chapter on Bax in Van Kolfschooten's Ontspoorde Wetenschap [Derailed Science] (2012) moved the board of the VU to establish a commission of investigation into the various allegations and accusations surrounding Bax.

But that is not the only faulty piece of information in Margry's memory of the Bax case. For example, on p. 138, Margry writes: "In the initial phase of the investigation of the Bax case, I was hesitant and was warned by colleagues at the VU that there was resistance against doing anything and that it 
would be better not to look for a scandal" - something that he attributes in note 30 to an email from Salemink on 15 September 2008. We maintain that Margry wants to suggest that (anthropologists at) the VU were - in contrast to Margry himself - reluctant to take any public action regarding Bax, but in fact this mail referred to the different opinions within Dutch anthropological circles at the time. In that very same mail, however, Salemink wrote that he preferred a response to Bax "according to the rules of common scientific debate", in this case, an article in Focaal. Any suggestion that as an ethnologist, Margry was the only scholar willing (but "hesitant") to engage with a case of scientific fraud, while anthropologists, and specifically Verrips and Salemink, were reluctant to this, is patently and demonstrably false.

\section{Falsification of Qualitative Research}

This points to a bigger issue regarding scientific misconduct within anthropology, ethnology and other qualitative social science and humanities disciplines, namely that even though science thrives on scholarly debate consisting of critique over research data, methodologies and theories, it is extremely difficult to falsify statements regarding empirical material. The Commission Baud (2013), established by the VU in 2012, could fairly easily prove that Bax had invented quite a few non-existing publications, but experienced difficulty in actually proving that the conflicts on which Bax had based many of his publications had never happened; or that the field site in Brabant - a monastery that he gave the pseudonym "Neerdonk" - did not in fact exist, as the journalists Van Kolfschooten (2012) and De Boer (2013) could claim. Referring to the ethical injunction within anthropology to protect informants through anonymization, Bax refused to divulge his sources and data (names of places and people) to the Commission Baud or, alternatively, claimed that he had thrown away all his material. In the natural sciences and quantitative social sciences, data are in principle objectified in datasets and hence accessible for others, and research experiments could (in principle and ideally) be replicated. In contrast, replicability does not work in the same manner in the social sciences (Kloos 1994), as qualitative social science research is always contextual, that is the findings are constructed by the researcher/author on the basis of embodied interactions with interlocutors and other research subjects. "Data" cannot be easily abstracted from those interactions, even if they can be objectified in notebooks and other formats. Thus, even if notebooks are made publicly accessible, the "openness and controllability" desired by Margry (2019: 139) is hard to achieve, because the contents of the notebooks depend on the context and on the relations between researcher and informants (and not others), and is always a snapshot in time.

If it was hard to accomplish for a well-endowed commission, it proved even more difficult for a small group of three colleagues who lacked research expertise in Bosnia to debunk some of Bax's confabulations. This was recognized in an email of 11 January 2012 from Margry to Salemink: "Jojada [Verrips] wanted me to write a piece about that in Focaal or something, but that remains somewhat complicated because in particular [Bax's] research in Bosnia-H. is much harder to evaluate than the fabrications [verzinsels] in his inaugural lecture. I started to ask colleagues there about it and their replies were all very negative about Bax and his work, but I did not receive concrete proofs." Having apparently forgotten about the plan to write a joint article with Verrips and Salemink, Margry did not elaborate what such concrete proofs might entail, but it is clear from this mail by Margry that proof of confabulation is hard to come by. For the record, until his recent article in Ethnologia Europaea seven years after the Circumventing Reality report by the Commission Baud (Baud, Legêne \& Pels 2013), Margry did not publicly expose any of Bax's fabrications about Brabant. Writing about the fieldwork and seeking to disprove the findings of another scholar takes an enormous time investment and is next to impossible without doing one's own field research (requiring investing in language and long-term stays in the region). If anything, Margry's public silence about Bax's research in Brabant suggests that proving confabulation is 
even difficult for fellow researchers with intimate knowledge of the topic - Catholic organizations and region - Noord-Brabant.

Particularly revealing in this regard is Margry's very sparse description of what happened in 2012 and 2013, the years in which Bax's fabrications were made public by both the journalist Van Kolfschooten and the Commission Baud. He only offers a few remarks on their startling disclosures followed by a long paraphrase of what Bax wrote about his mode of operation in his letter to Verrips of 19 June 2005 (see endnotes 19, 21, 22 and 23). Instead of presenting a list of striking figments of Bax's imagination as signalled by Margry himself, the journalist Van Kolfschooten and the Commission Baud, he indulges in a stunningly anachronistic exposé on Bax's evasive story on the way he did his research. Neither does he mention the fact that Verrips wrote Bax once again in 2012 with the request to reveal the name of the monastery and to be open about his sources before he would publicly be unmasked as a swindler and a cheat. Nor does he mention the extensive e-mail exchange between himself, Van Kolfschooten and Verrips on a possible field site which Bax studied that could have been the model for "Neerdonk".

\section{Constructing a Divisive Narrative}

In the article on the Bax case, Margry's use of sources is problematic. Not only did he use our personal email correspondence without our permission, he also, as we have shown above, omitted written sources that did not confirm his memory of the events, and used sources anachronistically. Furthermore, we find that in various places of his article, there are also problems with the interpretation of sources. Take, for example, how he uses a quote from an interview with Verrips in the second part of his article in which he deals with methodological and ethical issues. On page 140 of his article he refers to “...every scholar's lingering nightmare of being unmasked as a fraud". In the endnote at the end of this sentence he quotes Verrips in such a way that one might think that the latter spoke about his anxiety of being exposed as a fraud in the sense that Bax was one, whereas Verrips was obviously speaking about his worry with regard to possible critique on his line of argumentation. This so-called impostor syndrome is not uncommon among scholars, a fear that they are "imposters" as intellectuals, but does not mean that the person experiencing or expressing it is actually a liar. Bax arguably moulded or invented his data to support his theoretical views, which made him a scientific fraud, but that is not the same as fear or concern that one's analytical argument is liable to critique. Every scholar knows that mutual critique is fundamental to scholarly debate, and to the system of peer review that makes publishing and research funding possible.

Unfortunately, there are a number of demonstrable misinterpretations in Margry's article, that mould the material in such a way as to support his memory or - as he called it in an email of 2 April 2020 to Salemink - his "feeling" that all initiative had to come from him, and his impression of resistance on the part of others - anthropologists and the VU - to do something. The omissions and misinterpretations in the article support a narrative that suggests - rather than explicitly claims - that there was resistance among anthropologists and within Bax's former employer, the VU, against "doing something" to find out the "truth" about Bax's confabulations. The latter is demonstrably untrue, because the VU instituted a commission of investigation the moment claims about Bax's confabulations entered the public sphere in the Netherlands. The Commission Baud did not mince words about the seriousness of the issue, and its wider scholarly and academic implications. ${ }^{7}$ And the sources we have used for this article show that Margry's own feeling or impression, that Dutch anthropologists were not interested in investigating and effectively covered up Bax's misconduct, was inaccurate. He himself knows that we were willing to co-author an article pointing to the problems of Bax's research.

In our view, Margry has constructed a straw man in this article, and casts himself as a disciplinary outsider: " $[\mathrm{H}]$ aving been trained as a historian, and having worked since 1993 as a (European) ethnologist, I felt that I was not in a position to bring the work of an acknowledged cultural anthropologist into 
public disrepute" (Margry 2019: 135). Through this narrative device, Margry portrays himself as some kind of lone ethnological hero who develops doubts - and subsequently finds out - about Bax's fraud, but feels hampered to act on his indignation in the face of "resistance" from Dutch institutional anthropology, which in the article seems to be personified in Verrips and Salemink. But we wonder why this distinction was made so important. We would submit that anthropology and ethnology mean different things in different places, as illustrated by the name of the leading anthropology journal, American Ethnologist. And more pertinent to this case, although working in an anthropology department, Bax found it expedient to publish seven articles in the flagship journal of European ethnologists, Ethnologia Europaea. If the distinction overlaps with the former German distinction between Volkskunde (ethnology at home) and Völkerkunde (anthropology abroad), then it arguably becomes less and less meaningful in a globalizing and pluralizing world. Margry, however, gave this distinction as the reason - not only in the article, but also and regularly in earlier correspondence with Salemink and Verrips - why he did not take any action himself, even though he had a deep suspicion of Bax's confabulations in Brabant.

All that we have criticized in Margry's article so far would not have been necessary if he had stuck to his own advice "to have work discussed in a seminar or commented on by colleagues that can be trusted, also in the sense that they feel safe to critique the text and maybe pose uncomfortable questions" (2019: 139). Upon closer inspection, these nice words ring hollow with regard to the very article in which they appear. Margry stages himself therein as a lone rider, who in his quest to unmask Bax as an untrustworthy storyteller was left in the lurch by his anthropology colleagues, because they were too afraid of unwelcome scandals and of soiling the university. This offers a distorted representation of what happened and does not do justice to our efforts over the years to take the persistent rumours about Bax's fabrications seriously. And as argued above, turning suspicion into irrefutable proof is hard, for ethnologists and anthropologists alike.

\section{Anthropology, Ethnology and Research Ethics Regimes in Europe}

Whereas we disagree with the way that Margry narrated a sequence of events around the Bax case, and in the process painted an unflattering picture of Dutch anthropologists, it has the merit of bringing this distressing case to the attention of a wider public, and of drawing out some lessons:

[I]n our field - a humanistic, non-positivistic research environment - scientific laws, mathematical precision, or full verification are not possible. This means that our paradigm comes with a major responsibility: to deal as precisely, meticulously, and ethically as possible with sources and data and their interpretation. It is clear also that source material and research data do not belong exclusively to the researcher - they are too important in many respects to be left to any single individual. The greater the openness we maintain in respect of our sources, and the more extensive our accountability through open access to them, the more society will trust the academy, ultimately enhancing the robustness of humanities research and the meaning of its outcomes. (Margry 2019: 141)

Precision, ethics, openness, accountability and trust are lofty ideals that few serious humanities scholars would disagree with. But what are Margry's specific suggestions based on the lessons learned from his reading of Bax's fraud?

He finds that research data should not be considered the personal property of the individual researcher, and pleads for "openness and controllability" in the handling of and access to research data, which he juxtaposes to "the anthropological epistemology of private data, which enabled Bax's misconduct" (Margry 2019: 139). While uncharitably attributing Bax's fraud to "the anthropological epistemology", Margry confuses two things here. One is the conflation between private and personal. The expression "private data" refers to the privacy of information pertaining to research subjects, which since 2018 is covered under the EU's GDPR (adopted 
in 2016, and coming into force in 2018). But that is distinct from "personal data", which emerges in anthropology's preferred ethnographic method of participatory observation, where the researcher is her own, embodied, research instrument (Csordas 1990), and where knowledge is constructed intersubjectively, that is through the encounter between researcher, interlocutors and other research subjects (Pels 2014). This data is personal in the sense of methodologically and epistemologically connected with the researcher, and hence is difficult to make openly accessible. Yet personal data does not mean private data, as understood in the GDPR. As argued before, the methodological and epistemological aspect of ethnographic research makes it difficult to abstract embodied "data" from the researcher and her interaction with research subjects, and objectify such data in disembodied form as a dataset. Such objectification of data may be possible for qualitative research predicated on one-time interviews, but it is difficult to imagine how that could work for longterm, in-depth ethnographic field research primarily based on participatory observation.

The second thing Margry confuses is "anthropological epistemology" and anthropological research ethics. The latter has been laid out in a long series of very strict ethical codes of various anthropological associations, in particular the American Anthropological Association and the European Association of Social Anthropologists. Since the Vietnam War (in Vietnam known as the American War) in the 1960s and 1970s, the main injunction of these codes was to prevent any potential harm to research subjects, which is usually implemented through the use of anonyms and/or pseudonyms, and is still relevant today. Bax's abuse of this sacrosanct ethical injunction in anthropology to refuse divulgence of his sources and avoid scrutiny and accountability does not constitute an "anthropological epistemology". Thus, the problem is that the ethical injunction to protect one's research subjects gets in the way of the "openness and controllability" of sources and research data that Margry advocates, and hence - in the case of Bax - facilitated fraud.

Margry sees a risk in the GDPR, claiming that ironically, "the anthropological epistemology of pri- vate data, which enabled Bax's misconduct, actually fits with the new legal directives and ethical codes on data handling" (2019: 139). This statement does not seem grounded in deep understanding of "the anthropological epistemology", nor of the debate about its effects on the humanities (Pels et al. 2018; De Koning et al. 2019). Post-GDPR, institutionalized research guidelines do not necessarily ameliorate the situation for ethnographic researchers or their research subjects. In contradiction with the embodied (Csordas 1990) and intersubjective (Pels 2014) nature of ethnographic research - especially the method of participatory observation - the postGDPR research guidelines disembody data from the researcher and decontextualize it from their interaction with research subjects in the field. The data are abstracted and objectified, and as such must now be stored safely at the university or research institute, and not in the researcher's own home or office. In line with Margry's plea, data are now institutional rather than personal property, and are in principle accessible to others. But the idea of objectified, disembodied, anonymized research "data" stored "safely" in university archives and accessible to all is antithetical to much anthropological and other humanities research. Paradoxically, the GDPR's current privileging of states in deciding over the handling and "exporting" of data (imagine doing fieldwork in China, for instance) and the access to the data that others are granted, undermines anthropology's ethical injunction of "no harm".

Counterfactually and anachronistically, Bax would have been forced to divulge his data and sources if the current GDPR privacy protection framework would have been operational from the 1980s onward. However, given the lengths to which researchers must go to anonymize the identities of their research subjects to such a degree that data can no longer be traced to any individuals, it is questionable whether such "openness and controllability" would suffice to check the veracity of his ethnographic and historical claims about Brabant and Bosnia. Counterfactually and anachronistically again, given the present illegality of keeping research data at home, Bax would not have been able to fa- 
cilitate the Commission Baud after his formal retirement if the scandal would have broken out in present times. In other words, under the current GDPR regime it may be equally difficult to falsify research findings and actually prove confabulation as it was for the Commission Baud and for concerned colleagues, including Margry and the current authors of this article. The overarching problem is the divergent and sometimes contradictory epistemological, methodological and ethical demands on researchers, as there is a tension between the ethical injunction of protecting the privacy of research subjects on the one hand, and the methodological ideal of verification of data through transparency and ideally replicability of research. Even when these two poles are in logical tension with each other, their simultaneous strengthening through data management and research ethics frameworks squeezes the space for ethnographic and other humanities research, affecting anthropology and ethnology alike.

\section{Conclusion: Restoring the Subjectivity of "Research Subjects"}

Just like all human efforts predicated on trust, all scientific disciplines have plenty of cases of fraud, in spite of rules and regulations designed to exclude such possibility (like double-blind peer review). So what should be done in cases of suspicion of fraud or other scientific misconduct? In the case of Bax, three options presented themselves to us, the first being to contact the researcher and ask for clarification. This option was attempted twice by Verrips and also by Margry, but Bax's responses were not satisfactory. The second option is to write a scholarly critique, an article which questions the empirical claims the author has made and challenges him to prove their veracity. Margry, Salemink and Verrips planned to write such an article for Focaal, but this plan turned out to require more time, effort and expertise than the authors were able to spend, given other obligations and eventually sickness on the part of two of the three intended authors. The third option is to report suspicion to the competent scientific authorities with a view to starting an investigation over transgression of research ethics. This is a heavy and very costly instrument, which usually is only used in the most serious cases and if there are already strong indications of deceit. The Commission Baud was established immediately after the credibility of Bax's research had been publicly questioned in a book on scientific fraud (Van Kolfschooten 2012), but four years after his research had been questioned in the Balkans and in some German-language media (but without much impact in the Netherlands), and many more years after doubts surfaced about Bax's research in Brabant. Citing protection of research subjects, Bax tried - and for a long time managed to ward off inquisitive efforts.

Disciplines that use qualitative social science and humanities methods - like anthropology, ethnology and history - find themselves in a logically impossible situation. On the one hand there is the common methodological requirement that the empirical data are either (statistically) representative or empirically valid (in terms of predicated on actual relationships between researcher and research subjects), if not both. In terms of ethnography, the more contextual and other detail can be provided, the more credible the research material ${ }^{8}$ and its description, interpretation and analysis. On the other hand there is the present-day GDPR requirement of protection of privacy, demanding the complete anonymization of the data in order to make interlocutors untraceable even in "raw" research data. How can ethnologists and anthropologists deal constructively and even productively with these tensions?

In order to answer this question, we would like to return to the question of whether Bax would have been able to commit his ethnographic and historiographical fraud in the current, post-GDPR era. Margry is optimistic in this regard: "Digital technologies currently give us possibilities to increase such control. Some researchers made their fieldwork and other data already directly accessible digitally, for new research or for verification purposes" (2019: 139). He gives the example of an anthropologist who made her fieldnotes digitally accessible, including to informants. Juxtaposing anthropology and ethnology again, Margry claims that this would "align with the ethnological tradition of archive building 
and working with data also collected by others in the field, and in this way contributing through fieldwork to an incrementally built public repository of knowledge" (ibid.). While this has been attempted in anthropology, albeit without much success, ${ }^{9}$ it would be questionable whether such public access to research data would be legal under the current GDPR regime. The data would have to be anonymized to render them untraceable and hence unrecognizable for interested scholars and others, but any attempt to make them more recognizable (and hence potentially interesting to other anthropologists) would be ethically hazardous, especially in politically repressive states.

That said, Bax could commit his scholarly "sins" in a mostly pre-internet era. At present it has become much more difficult for researchers (but also journalists, missionaries, company bosses, state officials and politicians) to utter "nonsense" about their research subjects, because most have access to information on the internet and will use their voices in public debates in order to "talk back" to authoritative descriptions of them. They will not necessarily react to the (anonymized) research data themselves (which might only have interest for local intellectuals) but rather to the narratives constructed on the basis of qualitative research data. We would submit that for anthropologists and ethnologists alike, this talking back on the part of interlocutors is a welcome addition to the intersubjective co-construction of knowledge that is predicated on the very subjectivity of interlocutors and other research subjects as human beings, rather than reducing them to objectified research data. We argue that taking the subjectivity of research subjects seriously is the only respectful way of dealing with this paradox of replicability and ethics pertaining to all qualitative social science, namely to resist the objectification of humans to "data".

\section{Notes}

1 Bax formally retired in the summer of 2002, but he had already withdrawn from teaching, research and other activities at the Department of Social and Cultural Anthropology of the VU in the summer of 2001. Salemink joined that department as associate professor in September 2001, but never met Bax there.
2 E-mail from Margry to the three historians mentioned dated 23 December 2003 concerning “Bax' confabulaties" (with cc to Jojada Verrips). In this e-mail he presented a kind of summary of the main flaws and faults in Bax's inaugural lecture.

3 E-mail from Verrips to Margry dated 7 January 2004.

4 E-mail from Verrips to Margry dated 29 March 2005; E-mail from Margry to Verrips dated 29 March 2005.

5 Der Stammeskrieg von Medjugorje. Der Standard (Austria), 26 August 2008; Norbert Mappes-Niediek (2008), Krieg in Bosnien: Die Toten, die es nicht gab. Frankfurter Rundschau, 17 September 2008.

6 We have not asked these colleagues for permission to give their names or quote from this correspondence, so we refrain from doing so on the ethical grounds of protecting their privacy.

7 In its Preamble, the Commission Baud writes: "The issue at the centre of this report is distressing for everyone concerned. It firstly affects the reputation of a Dutch anthropologist, but there are also implications for the discipline of anthropology and its methodology. Furthermore, and not unimportantly, the issue affects a wide range of personal and professional relationships in the academic environment that are founded on expectations of honesty and transparency. Finally, there are ramifications for institutions and the way they operate, extending beyond universities and the funding and monitoring of academic research to the system of programme review committees, peer review, and scientific publishing. Academic relationships are based on trust in the scientific honesty of everyone involved. Any doubt, of any nature, about these crucial elements, leaves deep scars" (Baud, Legêne \& Pels 2013: 3).

8 Some anthropologists prefer the term "research material" to "research data", as the latter has an objectified but disembodied, de-subjectivized connotation.

9 The Human Relations Area Files operates the World Cultures database; see https://hraf.yale.edu/ (accessed 6 June 2020).

\section{References}

Baud, Michiel, Susan Legêne \& Peter Pels 2013: Circumventing Reality: Report on the Anthropological Work of Professor Emeritus M.M.G. Bax. Amsterdam: Vrije Universiteit, https://www.vu.nl/en/Images/20131112_Rapport_Commissie_Baud_Engelse_versie_definitief_tcm270-365093. pdf.

Csordas, Thomas J. 1990: Embodiment as a Paradigm for Anthropology. Ethos 18(1): 5-47. DOI: https://doi.org/ 10.1525/eth.1990.18.1.02a00010.

De Boer, Richard 2013: Het kaartenhuis van hoogleraar Bax: Wetenschapsfraude, Reportage Feit en Fictie op 
Voet van Oorlog [Prof. Bax's house of cards: Scientific fraud, Report of fact and fiction on a War footing]. De Volkskrant-Science section, 13 April 2013.

De Koning, Martijn, Birgit Meyer, Annelies Moors, Peter Pels 2019: Guidelines for Anthropological Research: Data Management, Ethics, and Integrity. Ethnography 20(2): 170-174. DOI: https://doi.org/10.1177/1466138119843 312.

Der Standard 2008: Der Stammeskrieg von Medjugorje. Der Standard (Austria), 26 August 2008.

European Commission 2016: General Data Protection Regulation, https://gdpr-info.eu/.

Kloos, Peter 1994: Replication, Restudy, and the Nature of Anthropological Fieldwork. In: René van der Veer, Marinus van IJzendoorn \& Jaan Valsiner (eds.), Reconstructing the Mind: Replicability in Research on Human Development. Norwood, NJ: Ablex, 37-56.

Mappes-Niediek, Norbert 2008: Krieg in Bosnien: Die Toten, die es nicht gab. Frankfurter Rundschau, 17 September 2008.
Margry, Peter 2019: On Scholarly Misconduct and Fraud, and What We Can Learn from It. Ethnologia Europaea 49(2): 133-144. DOI: https://doi.org/10.16995/ee.1646.

Pels, Peter 2014: After Objectivity: An Historical Approach to the Intersubjective in Ethnography. Hau: Journal of Ethnographic Theory 4(1): 211-236. DOI: https://doi. org/10.14318/hau4.1.009.

Pels, Peter et al. 2018: Data Management in Anthropology: The Next Phase in Ethics Governance? Social Anthropology/Anthropologie Sociale 26(3): 391-413. DOI: https:// doi.org/10.1111/1469-8676.12526.

Sandberg, Marie \& Monique Scheer 2019: Fabricating Data, Undermining Trust, or: Why We Omitted Work from Our Digital Archive: Editorial by the Joint Editors-inChief. Ethnologia Europaea 49(2): 5-7. DOI: https://doi. org/10.16995/ee.1801.

Van Kolfschooten, Frank 2012: Ontspoorde wetenschap: Over fraude, plagiaat en academische mores [Derailed science: About fraud, plagiarism and academic mores]. Amsterdam: Uitgeverij De Kring. 